Наталія Гапоненко, спеціаліст, Подільський спеціальний навчально-реабілітаційний соціально-економічний коледж, ID ORCID 0000-0002-3525-0697

DOI: $10.33099 / 2617-1775 / 2021-01 / 88-94$

\title{
ПРОФЕСІЙНІ НАВИЧКИ ФАХІВЦЯ: ПЕРЕДУМОВИ, МЕТА, СУТНІСТЬ
}

У статті проведено ретроспективний аналіз наукових досліджень щзодо формування професійних навичок фахівия взагалі і постачання на ринок праці конкурентоспроможного спеціаліста. Проаналізовано $i$ з'ясовано, щуо фахівиями досліджуються технології $i$ методики, критерії і показники, рівні і моделі підготовки тощя. Разом з цим, лише незначна кількість робіт пов'язана з дослідженням саме проблематики сформованості кінщевого результату. 3'ясовано, щз на всесвітньому економічному форумі серед основних навичок було виділено, насамперед, уміння комунікаиії, дискусії, креативності, адаптуванні та інші. Виявлено, що для розвитку необхідних навичок необхідно обирати певні інструменти в прочесі навчання (тренінги, семінари, диспути, круглі столи, вебінари, семінари під керівництвом модератора, онлайн-курси, курси підвищення кваліфікації, вивчення спеціальної літератури тощя).

Ключові слова: професійні навички фахівия, комунікативність, дискусія, креативность

Постановка проблеми. Кінець XX століття i початок нового характеризуються суттєвими досягненнями в галузях фізики, математики, хімї, біології, медицини, фармацевтики, техніки та науки в широкому розумінні цього слова. Вагомі внески, досягнення або суттєві відкриття відмічають Нобелевською премією. I хоча нобелевських лауреатів в галузі освіти не вбачалось, але ми прекрасно розуміємо, що отримання цієї премії стало можливим завдяки таланту і освіченості людей в тій чи іншій галузі, а це, в свою чергу, стало можливим саме завдяки освіті. Винаходи і відкриття у всіх галузях можливо було здійснити тільки завдяки саме навченості, а фактично компетентності фахівців, які ці відкриття робили. Поступово ми звикаємо до високого рівня технологічності нашого суспільства. Отже, постає питання в підготовці фахівців, що дозволять цю технологічність створювати, підтримувати і обслуговувати. І ось тут, знаходячись в тіні і не маючи жодного Нобелевського номінанта по факту, на передову підготовки фахівців у всіх галузях виходить саме освіта. Жодна людина не народжується 3 готовими знаннями, а отримує їх в процесі навчання. Ми вважаємо, що фахівець, що виходить із стін будь-якого навчального закладу, повинен бути готовим до роботи за фахом. Рівень його навченості, готовності і фактично компетентності повинен відповідати обраному фаху. Зміни, що відбуваються в суспільстві, відображаються і на вимогах до фахівця, що прийде працевлаштовуватись. Основна задача освітян і буде полягати в тому, щоб видати кінцевий продукт спеціаліста, який, фактично переступивши поріг навчального закладу після навчання. зможе одразу переступати вже наступний поріг фірми, організації, 
установи тощо і приступати до роботи за фахом. Ми вважаємо, що основна проблема і буде полягати саме в готовності навчального закладу та педагогів виконати свої обов'язки та здійснити таку підготовку особи, що вчиться опанувати ці знання і стати компетентним спеціалістом.

Аналіз останніх досліджень і публікацій. В наукових джерелах знаходимо безліч наукових праць, присвячених розв'язанню проблеми формування професійної компетентності у майбутніх фахівців. Зокрема у О. Атласова， О. Бойка， В. Болотова， Н. Волкова， Г. Гапоненка， Л. Дибкової, I. Зимньої, І. Зязюна, В. Кременя, Дж. Равена, В. Свистун, Г. Селевка, О. Торічного, А. Хуторського та багато інших.

Психолого-педагогічні аспекти формування навичок відображені в працях С. Архангельського, Ю. Бабанського, М. Гриньової, Є. Мілеряна, К. Платонова, Г. Селевка, Н. Тализіної, К. Ушинського.

Ми провели ретроспективний аналіз наукових досліджень зазначених вище науковців і ще багатьох інших, взагалі до 80 робіт, що дає нам змогу зробити висновок про зацікавлення науковою спільнотою темою формування професійної компетентності фахівця взагалі і постачанням на ринок праці конкурентоспроможного спеціаліста зокрема. Фахівцями досліджуються технології і методики, критерії і показники, рівні і моделі підготовки тощо. Разом 3 цим, лише незначна кількість робіт пов'язана 3 дослідженням саме проблематики сформованості кінцевого результату.

Метою статті є ретроспективний аналіз наукових досліджень щодо формування професійних навичок фахівця взагалі і постачання на ринок праці конкурентоспроможного спеціаліста.

Виклад основного матеріалу. В своїй статті ми хочемо підняти тему, що активно обговорюється науковою спільнотою, а саме перехід в системі освіти від школи знань до школи навиків. Що ми маємо на увазі? Традиційна система освіти давала знання, уміння і навички. Не перекреслюючи такий освітянський підхід, ми спробуємо акцентувати увагу саме на формуванні навичок. Чому не на знаннях і уміннях? На нашу думку, ми спробуємо довести, що саме навички фахівця в будь-якій галузі діяльності і будуть кінцевим продуктом фаховості або компетентності.

Існує безліч трактувань поняття «навички». Аналіз визначень цього терміну дає змогу констатувати, що це поєднання знань і вмінь, які отримані під час навчання і розвиваються упродовж подальшої роботи, дії, практичного виконання тощо. Тобто складовими навичок $є$ знання (сукупність інформації 3 будь-якої галузі, набутих у процесі навчання, дослідження тощо) та вміння (здобута на основі досвіду і знань здатність робити щось належним чином).

У своєму підручнику «Вікова та педагогічна психологія» В. Кутішенко подає наступне визначення терміну навички. Це - автоматизовані компоненти свідомої дії людини, які виробляються в процесі ії виконання. Однак ознакою сформованості навички $\epsilon$ якість дії, а не іiі автоматизація. Навичка розглядається як дія, доведена внаслідок багаторазових вправ до досконалості виконання [1]. 
Словник української мови дає наступне визначення навику. Це - уміння, набуте досвідом, звичкою, вправами... Практичні знання, досвід у якій-небудь галузі [2].

На всесвітньому економічному форумі серед основних навичок було виділено, насамперед, уміння комунікації, дискусії, креативності, адаптуванні та інші. Результати дослідження в Harvard University $i$ Stanford Research Institute спільно з фондом Carnegie Melon Foundation дають змогу стверджувати, що успіх керівника в роботі на $75 \%$ визначається м'якими навичками. Цікавий факт ми почерпнули 3 Всесвітнього економічного форуму, який відбувся у 2020 році. До 2025 року передбачається, що на ринку праці до 52\% усієї роботи буде виконуватися роботами. Серед необхідних навичок, які будуть затребувані у 2025 році, на форумі виділили: лідерство, креативність, оригінальність, ініціативність, гнучкість розуму, критичне мислення, впливовість, стресостійкість, технологічність, уміння програмувати i навчатись, уміння вирішувати проблеми, ініціативність та інші.

Н. Талікіна, зробивши кластерний аналіз вищезгаданих досліджень, стосовно питань навичок молоді XXI століття, сформувала матрицю навичок, провела їхню кластерізацію та виокремила чотири основні категорій навичок, які $\epsilon$ необхідними для молоді у XXI столітті: навчальні навички, які допомагають адаптуватися до робочого середовища та вдосконалювати свої знання, вміння і компетенції; навички грамотності, які допомагають розрізняти факти, публікувати інформацію, створювати технології, визначати достовірність джерел та інформації; соиіальні навички - здатність успішно й ефективно взаємодіяти з конкретними людьми або різними групами, досягаючи поставлених цілей; особистісні навички - якості людини, які певним чином характеризують їі особистість [3].

Спробуємо 3'ясувати думки інших науковців 3 цього приводу. Так, розглядаючи психологічні основи підготовки фахівців екстремальних професій, Н. Іванова зазначала, що аналіз існуючих наукових психологічних підходів (діяльнісного, особистісного, особистісно-діяльнісного, індивідуального, функціонального, системного, системно-структурного, системно-генетичного) щодо формування фахівців екстремальних професій та напрацювань, рекомендацій практиків дозволяє стверджувати, що для успішної діяльності їм необхідні три взаємопов'язаних складники. Перший - набуття професійних знань, умінь та навичок; другий - розвиток професійного мислення; третій формування необхідного особистісного потенціалу, без якого неможливо ефективно застосувати наявні знання на практиці, виконувати поставлені завдання. Разом 3 цим вона акцентувала увагу на те, що для якісної підготовки слід розвивати у фахівців професійне мислення та професійно важливі якості [4, с. 151]. Ми звернули увагу на те, що фахівець, виокремлюючи три взаємопов'язаних складники і доповнюючи їх ще іншими якостями, розглядає їх як складники, що допоможуть фахівцям екстремальних професій застосувати наявні знання на практиці. Тобто, як ми зазначали раніше, вся підготовка націлена на кінцеву мету і готовність до практичних дій. 
Державна служба зайнятості, аналізуючи затребуваність професій протягом останніх п’яти років, запропонувала ТОП 10 навичок, що притаманні спеціалістам найбільш затребуваних професій. $\mathrm{B}$ таблиці 1 подано порівняльний аналіз навичок 2015-2020 років і показано їх зміни під впливом часу [5].

Таблиияя 1

ТОП 10 навичок i ïx зміни протягом останніх п'яти років У 2020 році

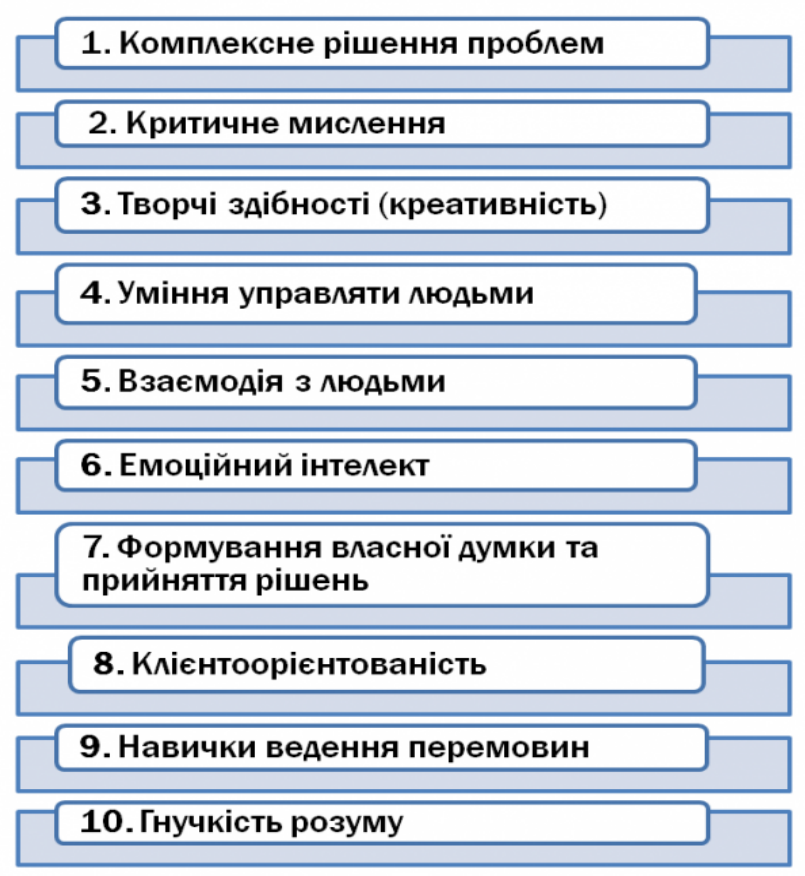

У 2015 році

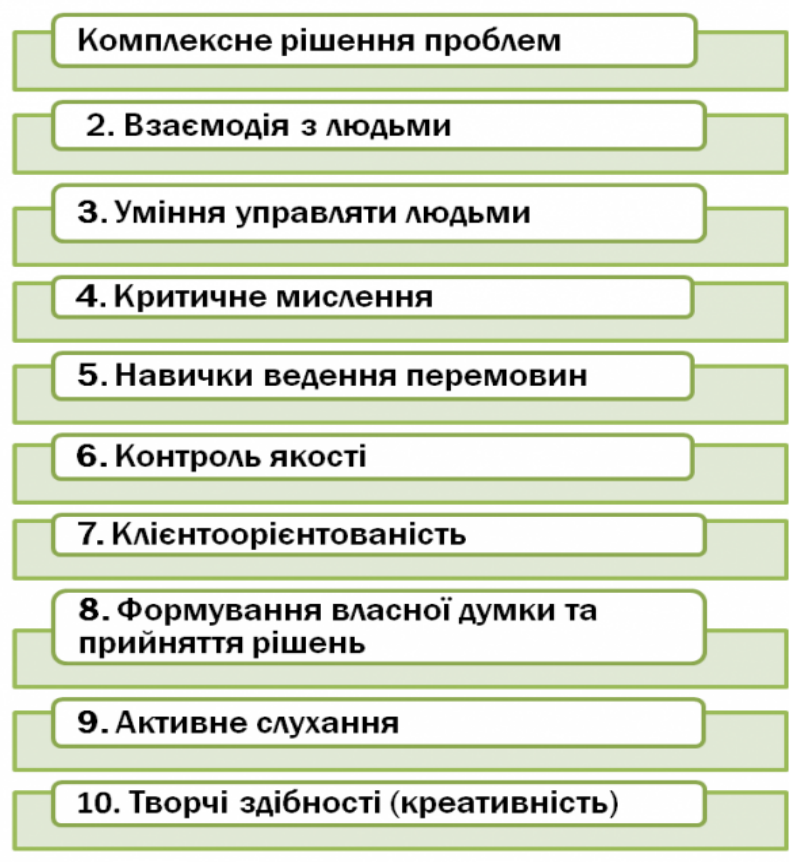

Для розвитку необхідних навичок необхідно обирати певні інструменти в процесі навчання (тренінги, семінари, диспути, круглі столи, вебінари, семінари під керівництвом модератора, онлайн-курси, курси підвищення кваліфікації, вивчення спеціальної літератури тощо).

Водночас слід визнати, що сформувати повністю готового до успішної діяльності фахівця в умовах навчального закладу неможливо, бо деякі професійні якості, особистісні характеристики утворюються тільки в процесі безпосередньої практичної діяльності. Там само набувається й професійний досвід. Центральною ланкою професіоналізму в структурі будь-якої діяльності $\epsilon$ методологія професійного мислення і сформовані на іiі основі моделі ефективних практичних дій [6, с. 192].

На думку, Л. Ітельсона, для розвитку навичок необхідно здійснити наступні етапи підготовки:

1. Ознайомлення 3 прийомами виконання дій. Осмислення дії та іiі подання. Чітке розуміння мети та способів іiі досягнення.

2. Опанування окремих елементів дії, аналіз способів їх виконання. Чітке розуміння способів виконання дій. Свідоме, однак невміле і нестійке іiі виконання. 
3. Співвідношення і об’єднання елементарних рухів в одну дію. Автоматизація елементів дії. Удосконалення рухів, усунення зайвих, перехід до мускульного контролю.

4. Опанування довільного регулювання характеру дії. Пластичне пристосування до ситуації. Гнучке, доцільне виконання дії.

Ми поділяємо думку цього та багатьох інших вчених і можемо зазначити, що проблема формування і подальшого розвитку навичок на устах у наукової спільноти і дослідницьких центрів та різних інститутів. Вона актуальна i потребує подальшого обговорення і осмислення, а в подальшому реалізації.

Висновки та перспективи подальших досліджень. В подальшому під час наших наукових досліджень плануємо з'ясувати умови, за яких можливе успішне формування навичок у молоді в XXI столітті.

\section{ЛІТЕРАТУРА}

1. Кутішенко В.П., Вікова та педагогічна психологія. Підручник. URL : https://pidru4niki.com/16900527/psihologiya (дата звернення: 06.02.2021).

2. Словник української мови. URL : https://slovnyk.ua/index.php (дата звернення: 06.02.2021).

3. Тілікіна Н.В., Навички XXI століття та умови їх формування і розвитку для молоді. 2020. URL : https://dismp.gov.ua/navychky-khkhi-stolittia-ta-umovy-ikh-formuvannia-irozvytku-dlia-molodi/ (дата звернення: 05.02.2021).

4. Іванова Н. Г. Психологічні основи підготовки фахівців екстремальних професій. Проблеми екстремальної та кризової психології. 2010. Вип.7. С. 148-157.

5. Донецький обласний центр зайнятості. 2020. URL : https://don.dcz.gov.ua/publikaciya/10-profesiynyh-navychok-yaki-budut-zatrebuvani-v2020-roci (дата звернення: 05.02.2021).

6. Педагогіка вищої школи: [навч. посібник / 3. Н. Курлянд, Р. І. Хмелюк, А. В. Семенова та ін.; / ред. 3. Н. Курлянд]. К.: Знання, 2005. 399 с.

\section{REFERENCES}

1. Kutishenko V.P., Vikova ta pedahohichna psykholohiya. Pidruchnyk. [Electronic resource]. - Access mode: https://pidru4niki.com/16900527/psihologiya (in Ukrainian).

2. Haponenko, H. (2015) Slovnyk ukrayins'koyi movy. [Electronic resource]. - Access mode: https://slovnyk.ua/index.php (in Ukrainian).

3. Tilikina N.V., Navychky KHKHI stolittya ta umovy yikh formuvannya i rozvytku dlya molodi. (2020) [Electronic resource]. - Access mode: https://dismp.gov.ua/navychky-khkhistolittia-ta-umovy-ikh-formuvannia-i-rozvytku-dlia-molodi (in Ukrainian).

4. Ivanova N. H. (2010) Psykholohichni osnovy pidhotovky fakhivtsiv ekstremal'nykh profesiy. Problemy ekstremal'noyi ta kryzovoyi psykholohiyi. 2010. Vyp.7. S. 148-157. (in Ukrainian).

5. Donets'kyy oblasnyy tsentr zaynyatosti. (2020). [Electronic resource]. - Access mode: https://don.dcz.gov.ua/publikaciya/10-profesiynyh-navychok-yaki-budut-zatrebuvani-v2020-roci (in Ukrainian).

6. Pedahohika vyshchoyi shkoly (2005) [navch. posibnyk / Z. N. Kurlyand, R. I. Khmelyuk, A. V. Semenova ta in.; / red. Z. N. Kurlyand]. K.: Znannya, 2005. 399 s. 


\section{РЕЗЮМЕ}

\section{Наталья Гапоненко, специалист, Подольский специальный учебно-реабилитационный социально-экономический колледж, ПРОФЕССИОНАЛЬНЫЕ НАВЫКИ СПЕЦИАЛИСТА: ПРЕДПОСЫЛКИ, ЦЕЛЬ, СУЩНОСТЬ.}

В статье проведен ретроспективный анализ научных исследований по формированию профессиональных навыков специалиста вообще $u$ поставки на рынок труда конкурентоспособного спечиалиста. Проанализированы и выяснено, что специалистами исследуются технологии и методики, критерии и показатели, уровни и модели подготовки и тому подобное. Вместе с тем, лишь незначительное количество работ связано с исследованием именно проблематики сформированности конечного результата. Выяснено, что на всемирном экономическом форуме среди основных навыков было выделено, прежде всего, умение коммуникации, дискуссии, креативности, адаптация и другие.

Выявлено, что для развития необходимых навыков необходимо выбирать определенные инструменты в прочессе обучения (тренинги, семинары, диспуты, круглье стольы, вебинары, семинары под руководством модератора, онлайн-курсы, курсы повымения квалификаџии, изучения специильной литературы и т.д.).

Ключевые слова: профессиональные навыки специилиста, коммуникативность, дискуссия, креативность.

\section{SUMMARI}

Natalia Haponenko, specialist, Podolsky special educational and rehabilitation socio-economic college

\section{PROFESSIONAL SKILLS OF THE SPECIALIST: PREREQUISITES, PURPOSE, ESSENCE.}

Introduction. The end of the XX century and the beginning of the new are characterized by significant achievements in the fields of physics, mathematics, chemistry, biology, medicine, pharmaceuticals, engineering and science in the broadest sense of the word. Inventions and discoveries in all fields could be made only through the training, and in fact the competence of specialists who made these discoveries. Gradually we get used to the high level of manufacturability of our society.

Thus, there is a question in the training of specialists who will allow to create, maintain and maintain this manufacturability. We believe that a specialist who leaves the walls of any educational institution should be ready to work in the specialty. The level of his training, readiness and actual competence must correspond to the chosen profession.

Purpose. The aim of the article is a retrospective analysis of scientific research on the formation of professional skills of a specialist in general and the supply of a competitive specialist to the labor market.

Results. At the World Economic Forum among the main skills were identified, first of all, the skills of communication, discussion, creativity, adaptation and others. Research from Harvard University and the Stanford Research Institute, in conjunction with the Carnegie Melon Foundation, suggests that 75\% of a manager's success is determined by soft skills. We learned an interesting fact from the World Economic Forum, which took place in 2020.

By 2025 it is estimated that up to 52\% of all work in the labor market will be performed by work. Among the necessary skills that will be in demand in 2025, the forum highlighted: leadership, 
creativity, originality, initiative, flexibility of mind, critical thinking, influence, technology, ability to program and learn, problem solving, initiative and others.

Originality. In our article we want to raise a topic that is actively discussed by the scientific community, namely the transition in the education system from a school of knowledge to a school of skills. What do we mean? The traditional education system provided knowledge, skills and abilities. Without crossing out such an educational approach, we will try to focus on the formation of skills. Why not on knowledge and skills? In our opinion, we will try to prove that the skills of a specialist in any field of activity will be the end product of professionalism or competence.

Conclusion. In the future, during our research, we plan to find out the conditions under which the successful development of skills in young people in the XXI century is possible.

Key words: professional skills of the specialist, communicativeness, discussion, creativity. 